\title{
Growth faults affecting depositional geometry, facies and sequence stratigraphy record on a carbonate platform edge (South Vercors Urgonian platform, SE France) ${ }^{\text {it }}$
}

\author{
Serge Ferry ${ }^{1, *}, \mathrm{a}$ and Danièle Grosheny ${ }^{2}$ \\ ${ }^{1}$ Université de Lyon, 6D avenue Général de Gaulle, 05100 Briançon, France \\ ${ }^{2}$ Université de Lorraine, ENSG, UMR CNRS 7359 GeoRessources, BP 10162, 54505 Vandoeuvre-lès-Nancy, France
}

Received: 21 February 2018 / Accepted: 30 November 2018

\begin{abstract}
The first two calcarenite units at the base of the Urgonian limestones on the southern edge of the platform bear different depositional geometries depending on place (Cirque d'Archiane to Montagnette and Rocher de Combau). The lower calcarenite unit (Bi5 of Arnaud H. 1981. De la plate-forme urgonienne au bassin vocontien. Le Barrémo-Bédoulien des Alpes occidentales entre Isère et Buëch (Vercors méridional, Diois oriental et Dévoluy). Géologie Alpine, Grenoble, Mémoire 12: 3. Disponible sur https://tel.archivesouvertes.fr/tel-00662966/document), is up to $200 \mathrm{~m}$ thick and shows three different patterns, in terms of accommodation space, from the western Archiane Cirque to the Montagnette to the east. On the western side of the Cirque, the unit begins on slope fine-grained limestone with thin sigmoïdal offlap geometry, suggesting little available space after a relative sea level fall. It is overlain by thick progradational/ aggradational, then purely aggradational calcarenite capped by a coral and rudist-bearing bed. This bed is, therefore, interpreted as a maximum (although moderate) flooding facies. The depositional geometry is different on the eastern side of the Cirque, where a progradational pattern in the lower part of the unit is interrupted by a rotational movement affecting the depositional profile. The deformation promoted aggradation updip and retrogradation downdip as a result of starvation. The inferred growth fault updip (thought to be responsible for the change) began to function earlier at the Montagnette, explaining the huge calcarenite clinoforms found there, filling a deeper saddle created in the depositional profile. The same fault probably was reactivated later during the deposition of the overlying, thinner Bi6-1 unit, which appears at Rocher de Combau with an uncommon tidal facies at the base. A rotational bulge, created by the inferred growth fault, would have protected a small area behind it to spare the local calcarenite deposition from the waves for a while. These two examples show that sequence stratigraphic interpretation may differ from one place to the other, and even show opposite trends due to this kind of disturbance.
\end{abstract}

Keywords: growth fault / carbonate platform / progradational geometry / sequence stratigraphy

Résumé - Failles de croissance affectant géométrie de dépôt, faciès et enregistrement séquentiel à
la limite externe d'une plate-forme carbonatée (Urgonien du Vercors méridional, SE France). Les deux
premières unités calcarénitiques constituant la base de la progradation urgonienne sur la marge sud de la
plate-forme montrent des géométries de dépôt différentes, voire des faciès inhabituels, du Cirque
d'Archiane à l'ouest, à la Montagnette à l'est. L'unité inférieure (Bi5 dans la nomenclature Arnaud H. 1981 .
De la plate-forme urgonienne au bassin vocontien. Le Barrémo-Bédoulien des Alpes occidentales entre Isère
et Buëch (Vercors méridional, Diois oriental et Dévoluy). Géologie Alpine, Grenoble, Mémoire 12: 3 .
Disponible sur https://tel.archives-ouvertes.fr/tel-00662966/document) épaisse de $200 \mathrm{~m}$ dans le Cirque
d'Archiane, montre une géométrie très rapidement progradante (offlap sigmoide indiquant un espace
d'accommodation réduit) puis lentement aggradante (augmentation de l'accommodation) sur la majeure
partie de son épaisseur, côté ouest du Cirque. La couche d'urgonien à coraux et rudistes qui termine l'unité

\footnotetext{
¿rit Cet article est écrit suite à une séance spécialisée de la SGF en

l'honneur d'Hubert Arnaud («Journées Hubert Arnaud»).

*Corresponding author: serge.ferry@yahoo.fr

${ }^{\text {a }}$ Retired.
} 
se dépose logiquement en régime transgressif (maximum d'inondation). Côté est du Cirque, la géométrie est différente. La progradation régulière de la partie inférieure est interrompue par un mouvement rotationel, qui piège le matériel calcarenitique dans la partie amont, fortement aggradante, et affame la partie aval, dès lors en régime rétrogradant. Une faille de croissance (tassement) à l'amont en est supposée responsable. Cette faille de croissance a fonctionné un peu plus tôt à la Montagnette, générant un ensellement plus profond, comblé par des clinoformes de progradation de grande taille. Elle a fonctionné à nouveau au début du dépôt de l'unité Bi6-1 suivante en créant, en arrière d'un bourrelet frontal aval probablement émergé, une zone protégée de la houle qui a permis la préservation locale et singulière de calcarénites à faciès tidal. Cet exemple démontre que l'analyse séquentielle peut changer complètement selon l'endroit où la coupe est levée, sur des bordures de plates-formes de ce type, à fort taux d'accumulation et donc instables.

Mots clés : faille de croissance / plate-forme carbonatée / géométrie de progradation / stratigraphie séquentielle

\section{Introduction}

Since the 1980s and the development of sequence stratigraphy, the South Vercors Urgonian (Barremian) carbonate platform has been widely known for its spectacular outcropping progradational geometries (Arnaud, 1981; Ravenne et al., 1987; Jacquin et al., 1991; Hunt \& Tucker, 1993; Everts et al., 1995), used over decades to train students in sedimentary geology. From detailed picture panoramas, the stratification in the cliffes of the Cirque d'Archiane have been analysed and compared to those of the Montagnette and Rocher de Combeau to the east (Fig. 1). The detailed observations commented hereafter have been gathered during successive field camps for Masters students of the Universities of Lyon and Strasbourg. Aside from the particularities observed in the internal geometry of the calcarenite wedges, the calcarenite succession of the Bi6-1 unit of Arnaud (1981) at the Rocher de Combeau also presents a tidedominated facies, which is very uncommon, in otherwise swelldominated peri-urgonian calcarenite units. This work highlights a logical explanation through the growth fault interpretation developed here.

\section{Stratigraphy}

The stratigraphic nomenclature used in this paper is the genuine lithostratigraphic scheme framed by Arnaud (Arnaud, 1981). The nomenclature evolved later to sequence stratigraphic ones (sequences termed $\mathrm{Ba} 1, \mathrm{Ba} 2 \ldots$ ), which are not used here, because they are interpretative, and also stained by long lasting stratigraphic controversies, following the papers of Clavel et al. (1987, 2014 and other references therein). Also, the sequence stratigraphic relationship between peri-Urgonian calcarenite wedges and coral/rudist-bearing true Urgonian facies have been questioned (Ferry, 2016), justifying the use of a lithostratigraphic nomenclature. The Barremian succession around the Archiane Cirque (Fig. 2) is very thick, exceeding $1000 \mathrm{~m} v \mathrm{~s}$. the 100 to $200 \mathrm{~m}$ commonly found in coeval basinal deposits of the Vocontian Trough to the south. The basal barremian deposits (Hs-Bi to Bil) are limestone-dominated. They outcrop on the eastern cliff (Pas de l'Essaure, Tête Chevalière). They consist of bedded, fine-grained limestones hosting large lenses of very coarse-grained calcarenite interpreted as ungraded proximal turbidites (Pas de l'Essaure) or slope gully infilling (Tête Chevalière). This unit does not outcrop in the Cirque d'Archiane.
The following $\mathrm{Bi} 2$ to $\mathrm{Bi} 4$ units are represented by the Fontaine Graillere Marls, around $350 \mathrm{~m}$ thick at the foot of the Montagnette summit (Bergerie de Combau). The first massive calcarenite unit $\mathrm{Bi5}$ ) representing the Urgonian progradation proper is approximately $200 \mathrm{~m}$ thick in the Cirque d'archiane (Fig. 2) and much thinner at La Montagnette. The overlying units in the Cirque d'Archiane (Fig. 2) comprise the Bi6-1 unit, approximately $35 \mathrm{~m}$ thick (thinning downdip) and a massive upper cliff comprising a number of units (Bi6-2, Bi6-3...). The interval between $\mathrm{Bi} 5$ and $\mathrm{Bi}-1$ (evenly-bedded calcarenite) is thin in the centre of the cirque d'Archiane. It thickens downdip to the basin (south) and becomes more marlstone prone (Fontaine Colombette Marls, in fact an alternation of calcarenite and slope mudstone or marlstone). On the basis of ammonites, the Fontaine Colombette Marls have been assigned to the Compressissima zone (mid lower Barremian) on the western side of the Montagnette cliff (Clavel et al., 2014). This paper is concerned only with the Bi5 and Bi6-1 units.

\section{Depositional geometries within the Bi5 unit}

A picture panorama taken on the westen cliff of the Glandasse plateau (Fig. 3) highlights the overall progradational geometry of the Urgonian calcarenite to the south. It also shows abrupt truncations interpreted as slump scars (Bievre \& Quesne, 2004). The slumped material has fed the many debris flow beds found southward in the Vocontian Trough (Ferry \& Flandrin, 1979; Ferry, 1987).

The detailed geometric analysis within the $\mathrm{Bi} 5$ unit has been completed along three N-S transects (T1 to T3, Fig. 1). Transect T1 follows the famous western cliff of the Cirque d'Archiane, often used as the landmark for the progradational geometry of the Vercors carbonate platform (Ravenne et al., 1987; Jacquin et al., 1991; Everts et al., 1995; Arnaud et al., 2017). T2 is along the eastern cliff of the Cirque. The easternmost T3 goes from the Montagnette to the Rocher de Combau downdip. The internal geometry of Bi5 along the T1 transect is as follows (Fig. 4): on the thick slope marlstone and limestone succession, the Bi5 calcarenite wedge begins rather sharply with a sigmoidal offlap, a few tens of metres thick. The geometry becomes both aggradational and progradational up section to finish mostly aggradational. The average grain-size of the calcarenite increases from botton to top, while the 

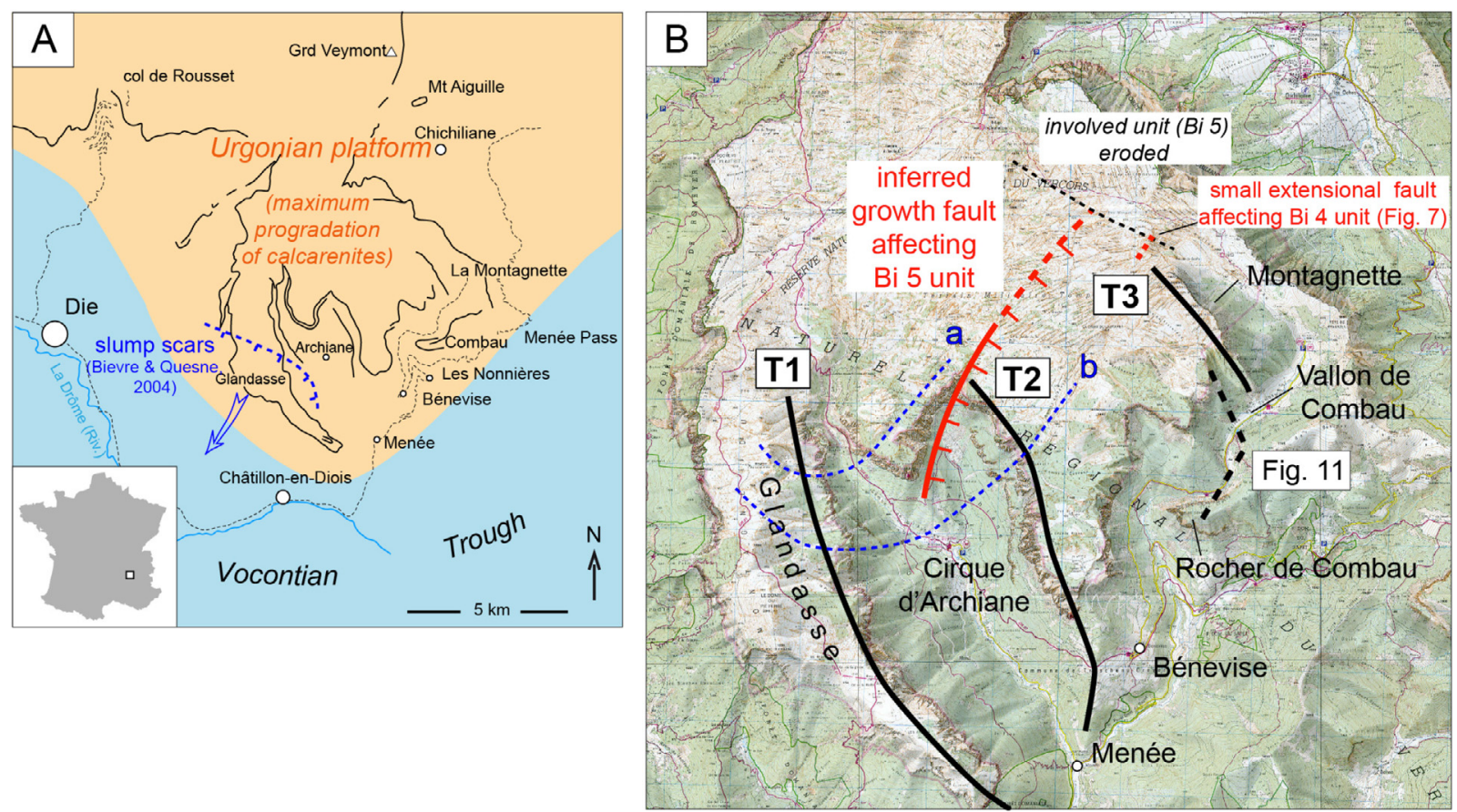

Fig. 1. Location map. A: the solid black line indicates the cliff line bordering the south Vercors plateau; dashed black line, main roads; B: heavy black lines, location of the transects T1 to T3 studied; dashed light blue lines, southernmost occurrence of coral-rudistid facies atop of calcarenite units (a, for Bi5; b for Bi6-1 units); T1, western Archiane transect; T2, eastern Archiane transect; T3, Montagnette-Combau transect.

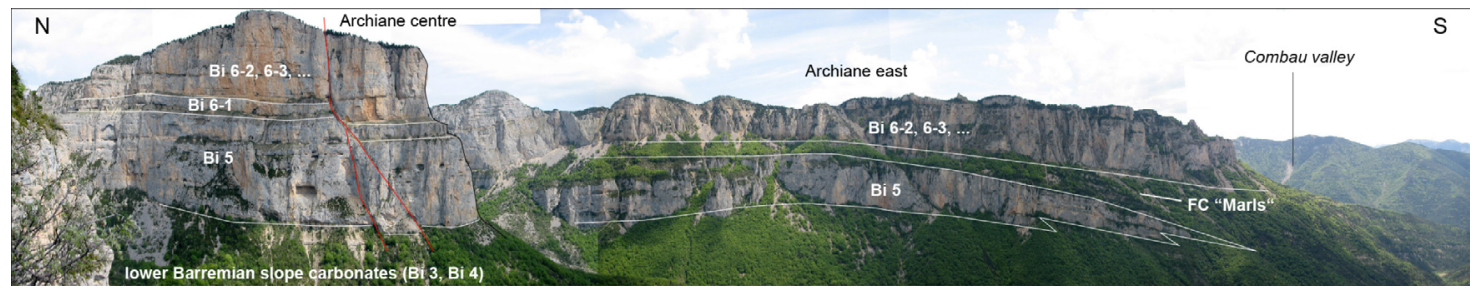

Fig. 2. Panoramic view of the Cirque d'Archiane, looking east, showing the Bi5 to Bi6 calcarenite units at the southern boundary of the Vercors Urgonian platform. Height of the cliff to the left is around $450 \mathrm{~m}$.
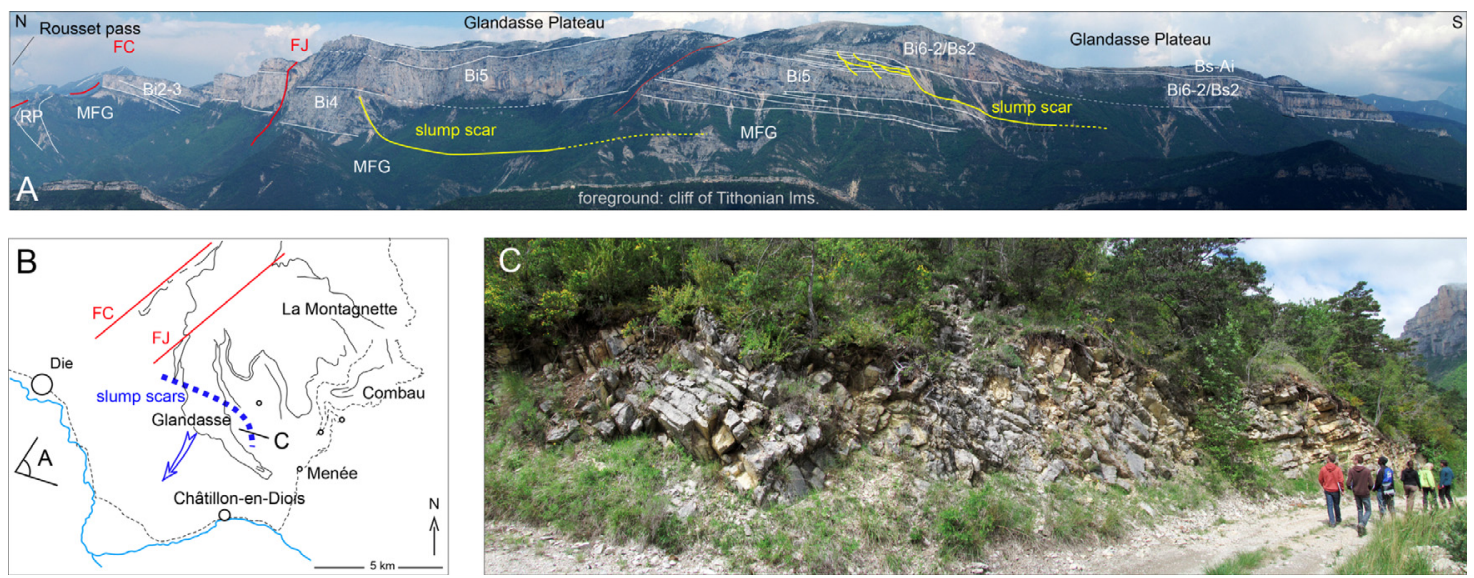

Fig. 3. A: western cliff of the Glandasse plateau overhanging the Drome River valley, showing the overall progradation to the south of the Urgonian calcarenite, and the abrupt truncations of the clinoforms by slump scars. Bi2 to Bi6 units follow the lithostratigraphic scheme of Arnaud (1981); MFG, lower Barremian Marnes de Fontaine Graillère; RP, termination of the lowermost Barremian Rochers du Parquet calcarenite unit; FC, Cléry fault; FJ, Jasneuf fault; B: location map showing the camera points for pictures A and C; C: disrupted megablocks of slope carbonates abandoned on the glide surface of the slump scar described by Bievre \& Quesne (2004). 


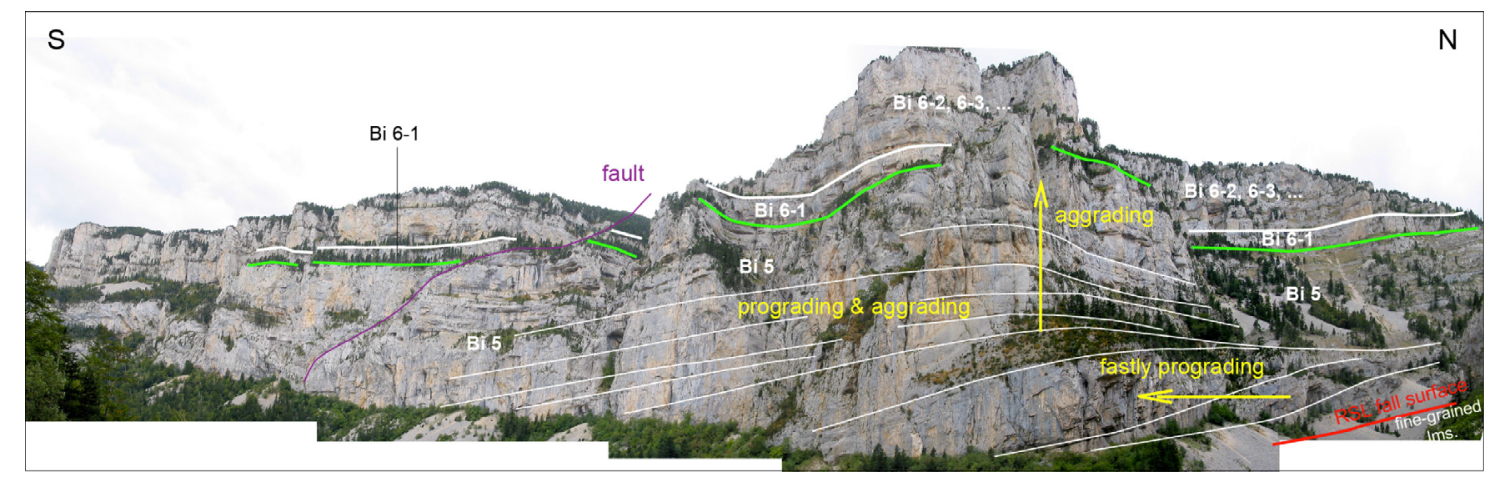

Fig. 4. Transect T1. Interpretation of the internal geometry of the Bi5 calcarenite unit. Red line, relative sea level (RSL) fall surface at base of the Bi 5 unit; green line, maximum flooding surface a the top of the Bi5 unit.

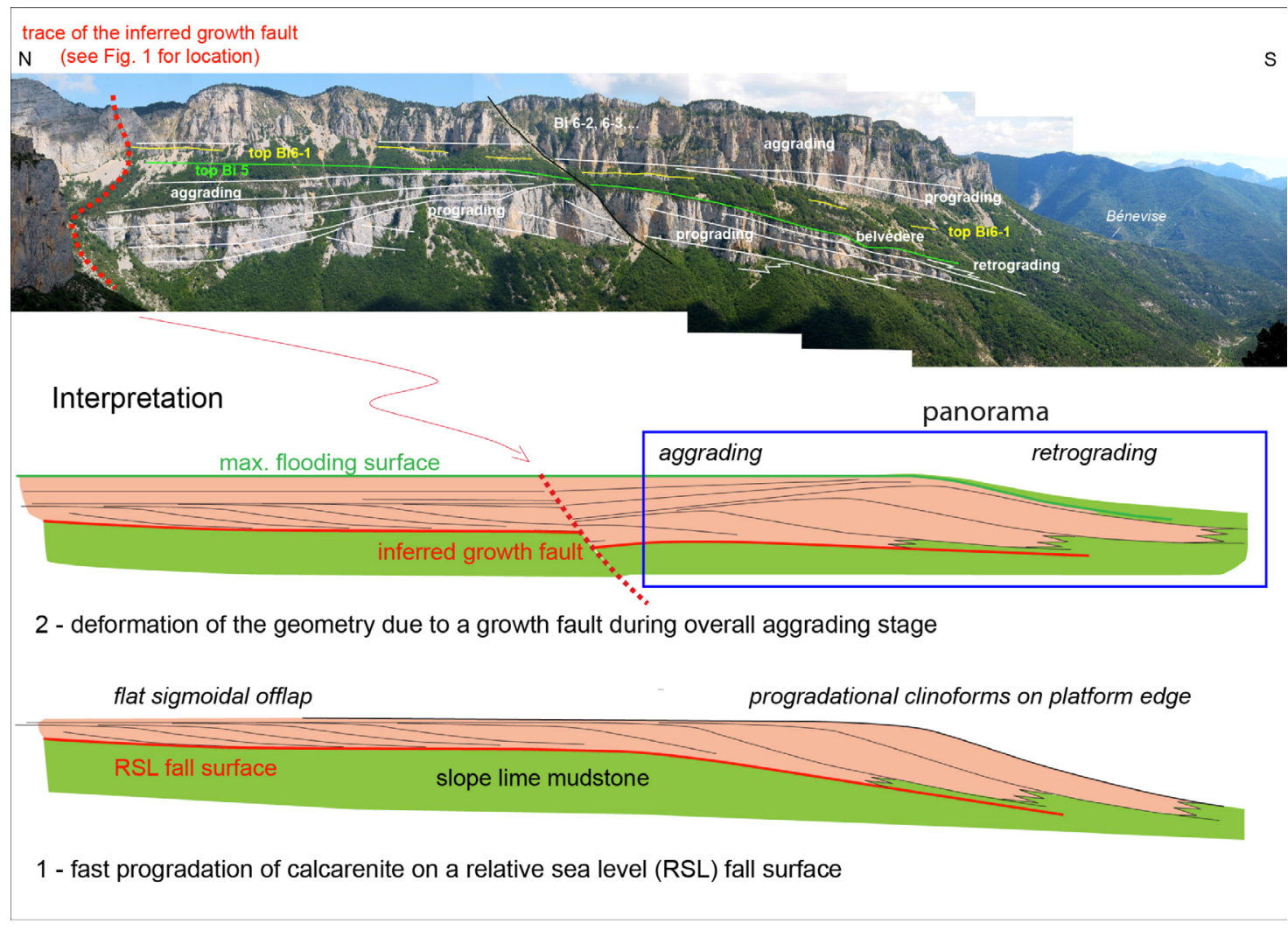

Fig. 5. Transect T2. Interpretation of the internal geometry of the Bi5 calcarenite unit.

sorting averagingly decreases. Scattered lenses of corals are found in the upper third (aggrading) of the calcarenite (Quatre Chemins trail to the plateau). A cap of white coral/rudistbearing bed, a few metres thick and transitionally deposited, finishes the sequence. The downdip termination of the wedge is truncated by a slump scar (Bievre \& Quesne, 2004). Its counterpart, along the Glandasse cliff overhanging the Drôme River valley to the west, also shows the same truncation. Huge blocks of more or less disrupted limestones can be observed on the glide surface in the western Cirque d'Archiane, along forest trails to the south (Fig. 3).

Transect T2 follows the eastern cliff of the Cirque d'Archiane. Its depositional geometry (Fig. 5) is different from what is found along transect $\mathrm{T} 1$. The wedge begins with a progradational geometry which is interrupted by a sudden change. Strong aggradation is then recorded in the updip part of the wedge, while a thin retrogradational corresponding subunit is found in the downdip part. The geometry is interpreted as a result of a syndepositional growth fault, situated updip from the aggradational geometry (Fig. 5). A thin sigmoidal offlap similar to that observed along transect T1 passes to a larger progradational geometry on the slope to the south. The inferred growth fault around the mid-deposition of the Bi5 unit then gulped the calcarenite supply from the platform, leading to smaller supply south of the bulge. It explains the occurrence of the thin retrogradational calcarenite 

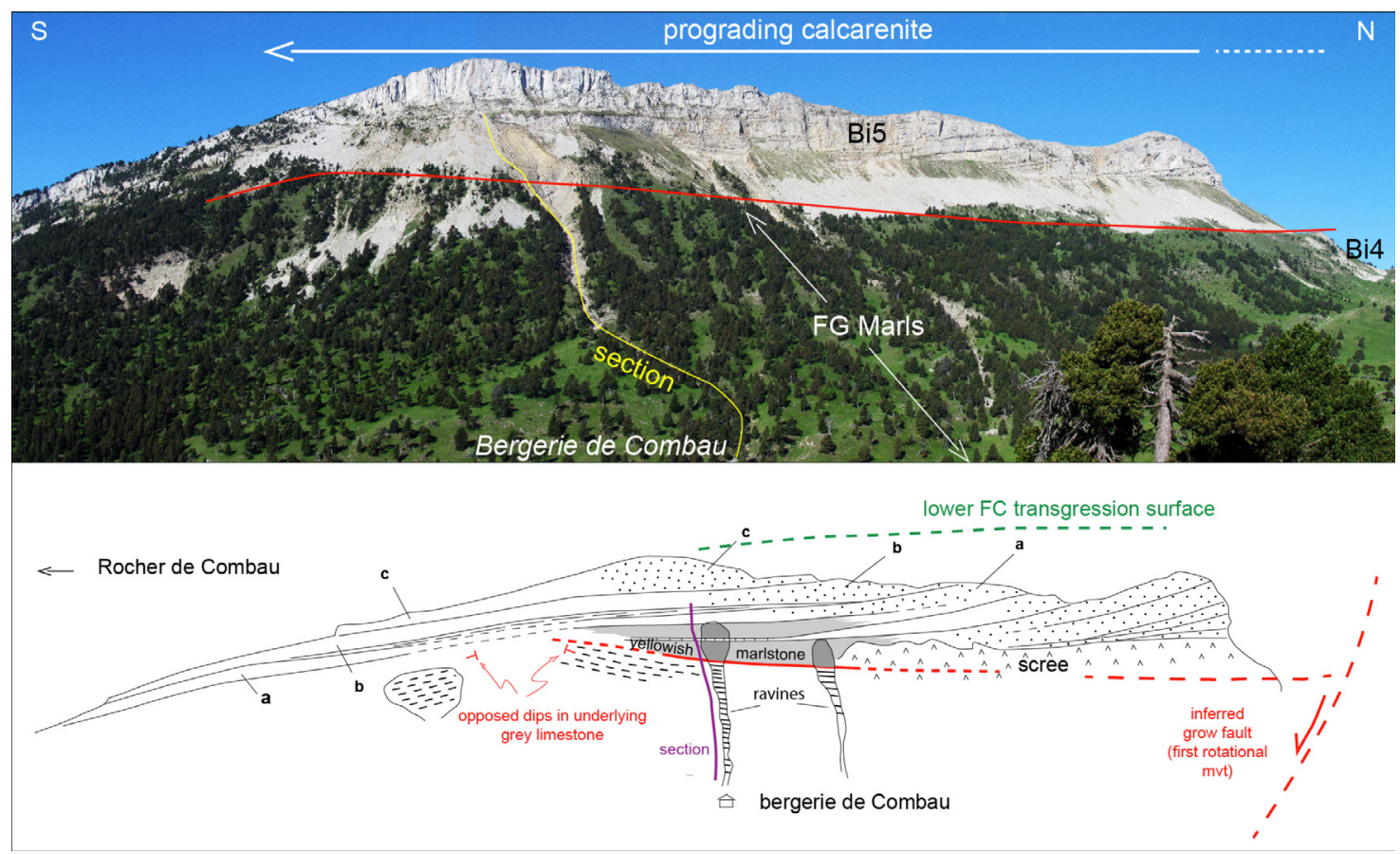

Fig. 6. Transect T3. Interpretation of the internal geometry of the Bi5 calcarenite unit. Red line, deformed geometry of the upper boundary of the Bi4 unit.

subunit on top of the southern (starved) part of the wedge (retrograding subunit in Fig. 5). The calcarenite of the Bi5 unit passes to the south to a thick bed of greyish, fine-grained slope limestones. This slope limestone is therefore thought to be mostly fed during the progradational part of the Bi5 calcarenite, although the connection is not visible along the present-day wooden lansdscape. No coral/rudist cap is found on this transect atop of Bi5, probably because, it is situated paleogeographycally a little downslope vs. T1 (see line b, in Fig. 1).

Transect T3 highlights the well-known progradational geometry along the Montagnette cliff (Fig. 6). Detailed analysis shows that, a change occurs within the upper third of the underlying $350 \mathrm{~m}$ thick Marnes de Fontaine Graillère (FG Marls, in Fig. 6) corresponding to the $\mathrm{Bi} 2$ to $\mathrm{Bi} 4$ units of Arnaud (Arnaud, 1981). Greyish marlstone and fine-grained limestone in the lower part pass to yellowish marlstone, within which the first calcarenite clinoforms of the Montagnette pinch out. The change is underlined in Figure 6. Opposed dips in underlying limestone, at the southern termination of the yellowish marlstone wedge suggest a change in the depositional slope. The last calcarenite clinoforms (a, b and c, shown in Fig. 6) largely spill over that inflection point to the south. As for transect T2, the overall figure is interpreted as the result of a growth fault located at a little updip. The rotational movement of that fault would explain the lensy geometry of the yellowish marlstone wedge. Compared to what is found along transect $\mathrm{T} 2$, the fault began to play at the base of the Bi5 unit. The first clinoforms began to fill a deeper hole, explaining that they pinch out within the yellowish marlstone wedge. When the hole was completely filled, calcarenite clinoforms spilled over to the south. The inferred growth fault (see in Fig. 1 for location) could be the same that is supposed to act along the $\mathrm{T} 2$ transect, which is very close. But its play would have began a little earlier, around the base of the $\mathrm{Bi} 5$ calcarenite at La Montagnette. The inferred growth fault cannot be located north of La Montagnette summit because corresponding deposits are now eroded (Fig. 1). But a little fault associated with a thickening wedge can be found (Fig. 7) in the underlying calcarenite units (Bi4), below the northern Montagnette summit. The orientation of the wedge suggests an earlier extensional play within the Bi4 unit. This little fault (Fig. 7) is therefore, interpreted as a precursor fault of the major growth fault inferred upslope.

\section{Sequence stratigraphic disturbances}

It should be first emphasised that the peri-Urgonian calcarenites usually do not bear tidal features. Most of the depositional features observed are swell-dominated (bedded tempestites, hummocky cross-stratification). In this kind of environment, the overall depositional geometry of a calcarenite unit is ruled by the position of the stormweather wave base above the bottom, which commands the available space for the deposit (Fig. 8). For instance, the updip part of the Bi5 unit along transect T1 (Fig. 4) begins with a thin sigmoidal offlap meaning there was very little available space after the fall in relative sea level that promoted the sudden occurrence of shallow-water calcarenite on previous fine-grained slope facies. To the south, when the water depth rises, the sigmoidal offlap passes to thicker clinoforms. It is what occurs in the lower part of Bi5 along transect T2 (Fig. 5).

The succession of facies in Bi5 on T1 (Fig. 4) suggests that, after the deposition of the basal sigmoidal offlap, available space gradually increased to the top, including the coral/rudistid cap. The succession is therefore mostly transgressive in terms of accommodation. In transect T2 (Fig. 5), the trend is disturbed by the play of the inferred growth fault. The southern part of the wedge shows a mostly prograding (regressive) trend interrupted by the thin retrogradational subunit at the top, below the full 


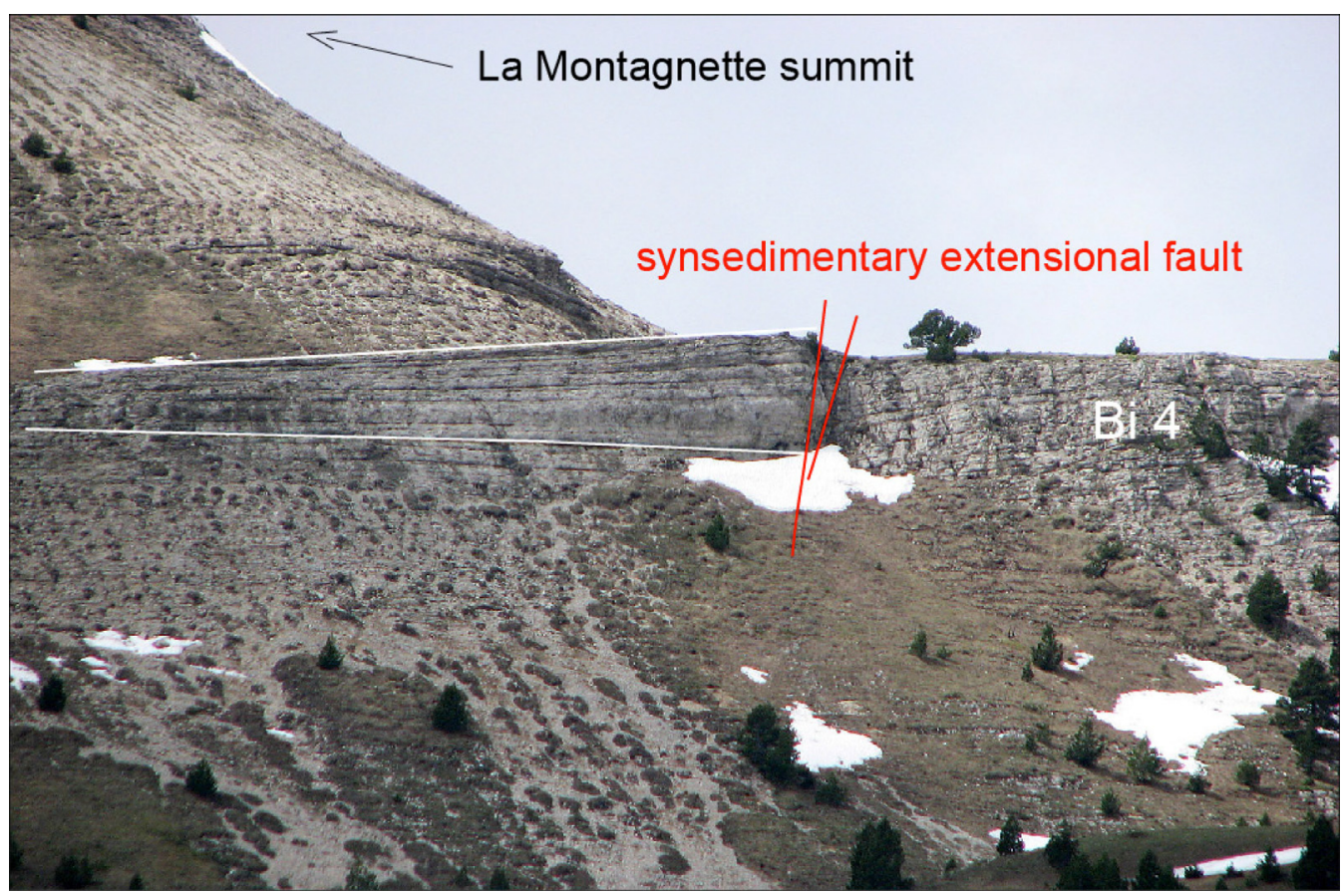

Fig. 7. Small extensional fault affecting the Bi4 unit (slope bioturbated calcarenite) just north of the Montagnette summit.

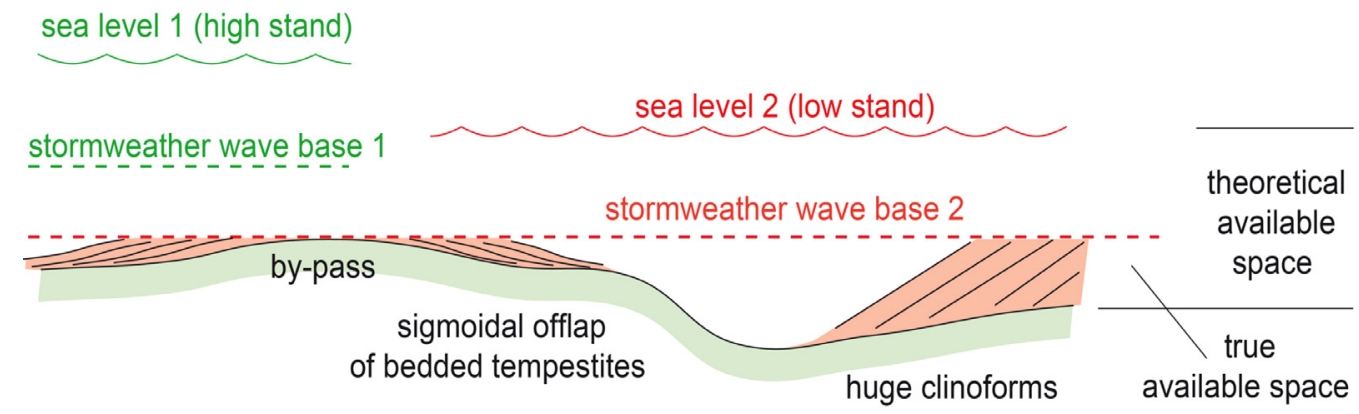

Fig. 8. Cartoon explaining the depositional geometry of calcarenite after a relative sea level fall, depending on the available space left.

transgressive pattern of the Fontaine Colombette Marls. Along transect T3 (Fig. 6), the Montagnette clinoforms are arranged into a full progradational trend up to the top, under the transgressive surface at base of the Fontaine Colombette Marls. In summary, the Bi5 calcarenite unit may bear strictly opposed trends in terms of relative sea level change depending on the place the sequence stratigraphic analysis is done (Fig. 9).

\section{Uncommon occurrence of a tidal facies at base of the Bi6-1 unit at Rocher de Combau}

All calcarenite deposits around the Cirque d'Archiane and at the Montagnette are either evenly-bedded (most-often) or may locally show hummocky cross-stratification. Thickness of beds are usually around a ten of centimetres. Their basal surface is sharp, either plane or slightly undulating (erosional). The internal structure of the huge clinoforms at la Montagnette also has parallel bedding, perfectly, following the inclination of the clinoform slope. It is only at the toe of the slope of clinoforms that cross-bedding may be found. Analysis of the cross beds suggests these features are due to the superimposition of small prograding lobes at the foot of the clinoforms. All the observed features therefore suggest a depositional environment mostly under the action of storms that either flushed the calcarenite material on a gentle depositional profile (Cirque d'Archiane), or along the avalanching slope of steeper clinoforms (La Montagnette). Such storm-dominated even bedding is found at the Rocher de Combau (Figs. 10a and 10b). It is only over a small area around the Rocher de Combau that metre-scale tangential cross-bedding is encountered at the base of the Bi6-1 unit (Fig. 10c). Tangential cross-bedding is not in itself a proof of tidal currents as similar features may also be created by shoaling waves in swell-dominated shores (lunate megaripples) (Clifton 1987), or hummocks in tide-influenced, swell-dominated shores (Vaucher et al., 2018, and other references therein). The most common distinctive feature is the occurrence of erosion in the bottomsets of tide-influenced hummocks or lunate megaripples (Ferry, 2015). These never occur within the bottomsets of tidal megaripples due to the steadiness of currents at maximum speed. It has been suggested that the progressive nesting of laminae in the 
Archiane-west

(T1)
Archiane-East

(T2)
Montagnette

(T3)

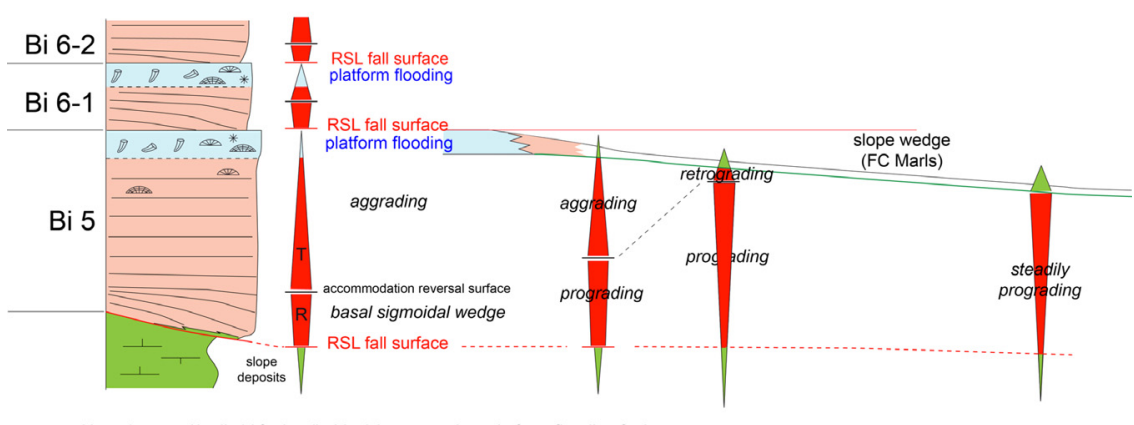

true Urgonian coral/rudistid facies (in blue) interpreted as platform flooding facies

Fig. 9. Disturbances of the sequence stratigraphic record of the Bi5 unit, depending on locations along the strike of the depositional system, due to the play of a growth fault.
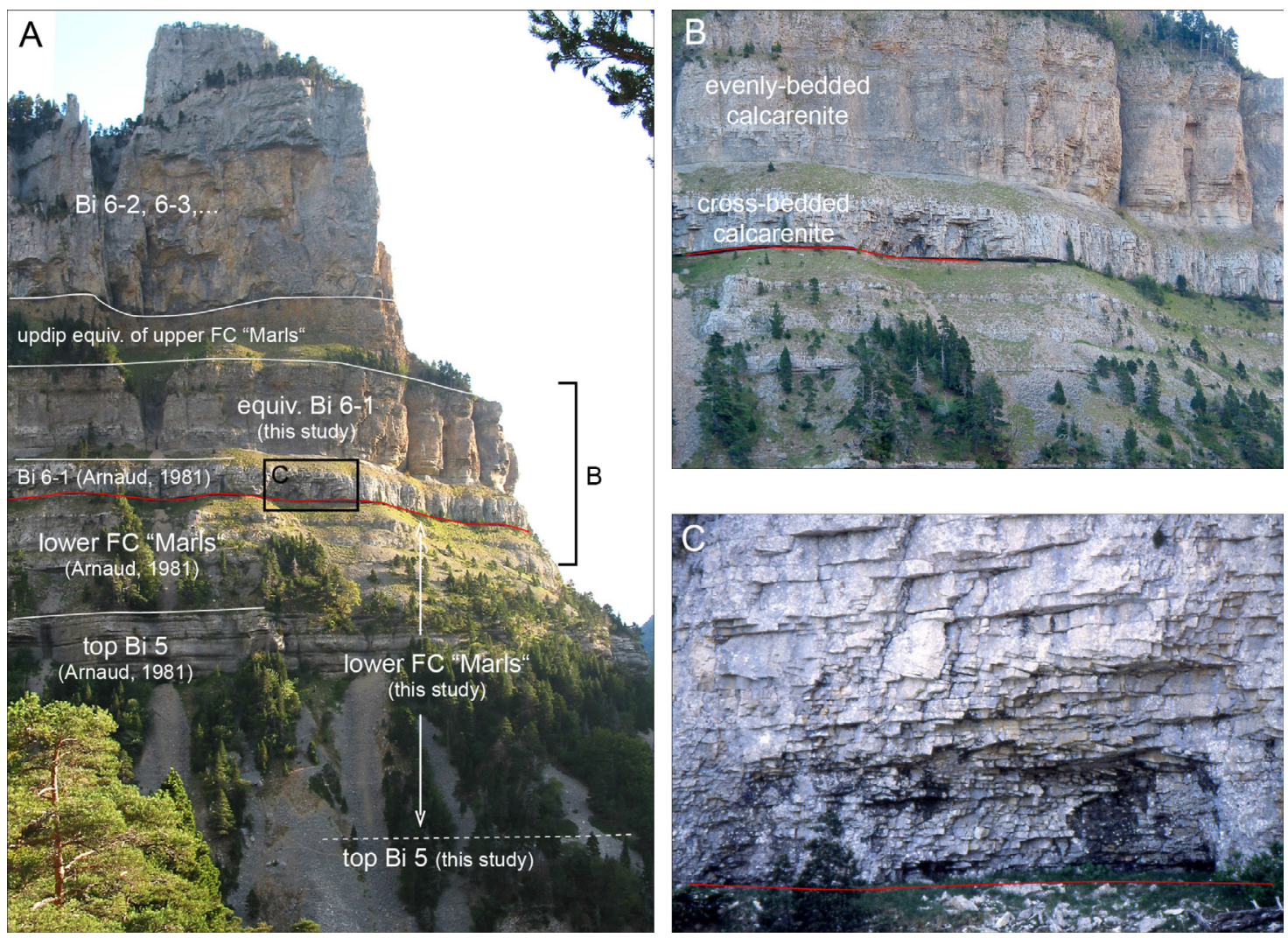

Fig. 10. Panorama of the Rocher de Combau. A: general view showing the changes in lithostratigraphic boundaries from Arnaud (1981), as a result of serial sections logged between the Montagnette and the Rocher de Combau this study); B: detail of the Bi5 unit showing the stratal patterns of the calcarenites from the base to the top of the unit, especially the even stratification attributed to storm deposits in the upper part of the unit; $\mathrm{C}$ : detail of the sigmoidal tangential bedding attributed to tidal megaripples separated by reactivation surfaces at base of the Bi5 unit. Also note the sharp base of the unit above the lower Fontaine Colombette (FC) "Marls" of Arnaud (1981).

bottomsets of laterally-accreting hummocks could be due to the increasing influence on the bottom of the orbital motion of the waves during the ebb half cycle (Ferry, 2015), although Vaucher et al. (2018) proposed an alternative interpretation. The tangential cross-bedding observed at Rocher de Combau is regular, without nesting features in the bottomsets. It is therefore attributed to tidal currents rather than to swell features (lunate megaripples), even in the absence of tidal characteristics like slack water mud drapes which only occur in mud-rich systems, and the lack of any spring-neap cyclicity in the progradation of the megaripples, probably due to the coarseness of the calcarenite material. The stacking of the observed calcarenite megaripples therefore goes from purely tidal at the base to tidal but storm-influenced upsection, as storm reactivation surfaces increasingly truncate the megaripples. A few metres from the base, the calcarenite becomes 


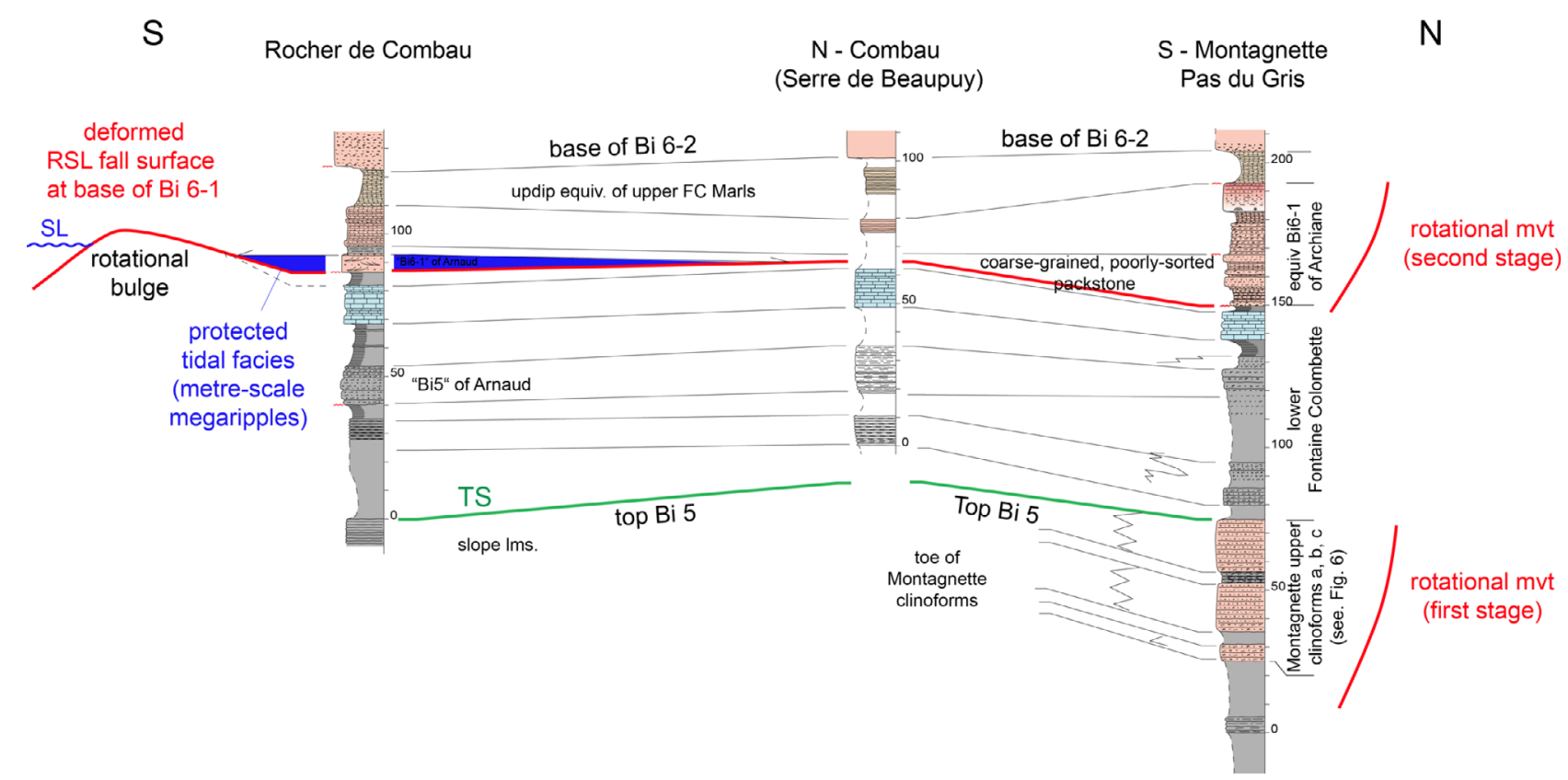

Fig. 11. Correlation along the distal part of the T3 transect explaining the unusual occurrence of a tidal facies (Rocher de Combau) at base of the Bi6-1 unit.

entirely storm-dominated (Fig. 10b). This succession suggest that an open environment succeeded to a protected one, in our interpretation of the sedimentary features.

The occurrence of the tidal facies has an explanation through the serial sections logged and correlated from the south Montagnette to Rocher de Combau. The correlation diagram (Fig. 11) begins at the toe of the Montagnette clinoforms ( $\mathrm{a}, \mathrm{b}$ and $\mathrm{c}$ subunits, Fig. 6). It is based on the tracing of key-bed (underlined in light blue in Fig. 11), a finegrained limestone bed, about ten metres thick, in the middle of the Fontaine Colombette Marls. This bed represents the maximum flooding between the calcarenite lowstand wedges of units Bi5 and Bi6-1. As in previous $\mathrm{T} 1$ to $\mathrm{T} 3$ transects, the Bi5 unit is bounded at base by a relative sea level (RSL) fall surface that sharply superimposes coarse-grained calcarenite on deeper-water marlstone (heavy red line, Figs. 10 and 11). This sea-level change is about coeval with the distal occurrence of the tidal calcarenite (underlined in dark blue, Fig. 11) on the RSL fall surface. The simplest explanation is that the growth fault inferred to be responsible of the clinoform geometry of the Montagnette $\mathrm{Bi} 5$ calcarenite (discussed above) resumed its play to deform the sea bottom in a more distal position at the beginning of the deposition of the Bi6-1 lowstand calcarenite. The forebulge of the rotational lens would have been exposed, therefore providing protection from the waves just behind. The rotational movement would also explain that the Bi6-1 calcarenite unit is thicker than normal updip ( $40 \mathrm{~m}$ against a ten of metres in the nearby $\mathrm{T} 2$ transect).

\section{Conclusions}

Analysis of depositional geometries within the outer calcarenite wedge fringing the South Vercors Urgonian platform shows a lateral sequence of stratigraphic heterogeneities that are interpreted as resulting from deformations of the depositional profile due to a growth fault. The fault operated in two successive phases, first during the deposition of the Bi5 calcarenite unit, then at base of the overlying Bi6-1 unit. In the Bi5 unit, the sequence stratigraphic record may show opposite patterns (mostly aggradational or fully progradational) depending on places (western Archiane Cirque $v s$. Montagnette, respectively). After a regional fall in relative sea level at the base of the Bi6-1 unit, the second rotational move of the growth fault allowed the local occurrence of a protected area, preserving a pure tidal facies in the calcarenite behind the front bulge at Rocher de Combau. These two examples show how strong the distortion of the facies and stratigraphic records induced by growth faults may be in fastly accumulating periplatform wedges.

Acknowledgements. The comments of an anonymous reviewer and Associate Editor P-Y Collin helped to improve the original manuscript.

\section{References}

Arnaud H. 1981. De la plate-forme urgonienne au bassin vocontien. Le Barrémo-Bédoulien des Alpes occidentales entre Isère et Buëch (Vercors méridional, Diois oriental et Dévoluy). Géologie Alpine, Grenoble, Mémoire 12: 3. Disponible sur https://tel.archivesouvertes.fr/tel-00662966/document.

Arnaud H, Arnaud-Vanneau A, Godet A, Adatte T, Massonnat G. 2017. Barremian platform carbonates from the eastern Vercors Massif, France: organization of depositional geometries. $A A P G$ Bulletin 101: 485-493.

Bievre G, Quesne D. 2004. Synsedimentary collapse on a carbonate platform margin (lower Barremian, southern Vercors, SE France). Geodiversitas 22: 169-184.

Clavel B, Charollais J, Busnardo R. 1987. Données biostratigraphiques nouvelles sur l'apparition des faciès urgoniens du Jura au Vercors). Eclogae Geologicae Helvetiae 80: 59-68. 
Clavel B, Charollais J, Busnardo R, Granier B, Conrad M, Desjacques $\mathrm{P}$, et al. 2014. La plate-forme carbonatée urgonienne (Hauterivien supérieur-Aptien inférieur) dans le Sud-Est de la France et en Suisse. Synthèse. Archives des Sciences, Genève 67 (1): 1-97.

Clifton HE. 1987. Wave-formed sedimentary structures. A conceptual model. In: Davis RA, Ethington RL, ed. Beach and nearshore sedimentation. SEPM Special Publication 24: pp. 126-148.

Everts AJW, Stafleu J, Schlager W, Fouke BW, Zwart E. 1995. Stratal patterns, sediment composition, and sequence stratigraphy at the margin of the Vercors carbonate platform (Lower Cretaceous, SE France). Journal of Sedimentary Research B65(1): 119-131.

Ferry S. 1987. Le détritisme carbonaté profond dans le Crétacé inférieur du Sud-Est français. Ses rapports avec l'esutatisme. Géologie Alpine Grenoble, Mémoire H.S. 13: 197-202.

Ferry S. 2015. Influence du cycle de marée sur les HCS littoraux. Données comparées de plages actuelles et de séquences côtières anciennes. $15^{\circ}$ Congrès Français de Sédimentologie, Chambéry, 13-15 octobre 2015. PDF file disponible sur https://www. researchgate.net/publication/323114332_Ferry-ASF2015-HCS.

Ferry S. 2016. Loi de Walther et modèles de faciès a priori. Un cas d'école: les calcaires urgoniens subalpins). $25^{\circ}$ RST, Caen (résumé). Livre en dépôt à la Société géologique de France.
Supplementary PDF file disponible sur https://www.researchgate. net/publication/3097338954.

Ferry S, Flandrin J. 1979. Mégabrèches de resédimentation, lacunes mécaniques et pseudo-"hard-grounds" sur la marge vocontienne au Barrémien et à l'Aptien inférieur (Sud-Est de la France). Géologie Alpine Grenoble 55: 75-92.

Hunt D, Tucker ME. 1993. Sequence stratigraphy of carbonate shelves with an example from the mid-Cretaceous (Urgonian) of southeast France. Special Publication International Association Sedimentologists 18: 307-341.

Jacquin T, Arnaud-Vanneau A, Arnaud H, Ravenne C, Vail PR. 1991. Systems tracts and depositional sequences in a carbonate setting: a study of continuous outcrops from platform to basin at the scale of seismic lines. Marine and Petroleum Geology 8: 122-139.

Ravenne C, Le Quellec P, Valery P, Vially R. 1987. Passive Margins: deep clastic carbonate deposits of the bahamas-Comparison with mesozoic outcrops of the vercors and vocontian trough. In: Bally AW, ed. Atlas of seismic stratigraphy. AAPG studies in Geology 27(2): 104-139.

Vaucher R, Pittet B, Humbert T, Ferry S. 2018. Large-scale bedforms induced by supercritical flows and wave-wave interference in the intertidal zone (Cap-Ferrt, France). Geo-Marine Letters 38(3): 287-305.

Cite this article as: Ferry S, Grosheny D. 2019. Growth faults affecting depositional geometry, facies and sequence stratigraphy record on a carbonate platform edge (South Vercors Urgonian platform, SE France), BSGF - Earth Sciences Bulletin 190. 